\title{
From east to west, can feminist legal strategies be transformative? Post-disaster to everyday times of crisis
}

\author{
Jane Krishnadas ${ }^{1}$
}

Published online: 22 November 2019

(c) The Author(s) 2019

\begin{abstract}
This article engages with a key question raised by feminist legal scholars from the east to the west: whether women should or should not engage in rights strategies? Are rights systematically exercised to reproduce patriarchal, dominant sites of justice, or do rights constitute a multiple and relational force which may transform sites of justice? The experience of women's engagements with law in South Asia has created a diversity of critical legal knowledge and scholarship reflecting the pluralism of both women's identities and needs based on caste, religion, class and sexuality across an array of legal spaces from the family, community and state. Women in South Asian scholarship have complicated the notion of the homogenous legal subject and the static dominant site of justice. In this article I return to my underpinning field research whilst living and working within an earthquake affected area of Maharashtra, India in the post-crisis rehabilitation period (1993-1998). This research explored how women exercised their rights to reconstruct lives at different tiers of justice: in public policy, private legislation and the non-formal sphere of community relations to deconstruct the concept of rights existing within a static framework of justice. Drawing upon feminist discourse across the east to the west, I have analysed the role of rights in post-disaster sites to understand how women move from victims to survivors, beneficiaries to contributors and objects to agents of change to inform contemporary research on how women in post-domestic violence situations may exercise rights to reconstruct their lives in times of crisis in the UK. Through this analysis I argue that rights may be empowering if one can exercise one's right to identity as agency, resources as capacity and location as mobility, as a three dimensional strategy to transform the framework in which one is situated. Over the last decade, I have actively applied this transformative methodology to create an alternative relational, intersectional and holistic legal paradigm, to transform sites of justice, in times of every day crisis, through the CLOCK/ All India Access to Justice Strategy.
\end{abstract}

Dr Jane Krishnadas-Director of Legal Outreach, Convenor of CLOCK, Senior Lecturer in Law, Keele University

Extended author information available on the last page of the article 
Keywords Women $\cdot$ Law $\cdot$ Pluralism $\cdot$ Transformation $\cdot$ Rights $\cdot$ Strategies

\section{Can rights strategies be transformative? From post-disaster to everyday life}

At a meeting organised by the Prayag Mahila Samity (women's organisation), Allahabad in May 1926, Sarojini Naidu told the crowd of assembled women that "it was not for men to give them or not to give them any rights; nor was it appropriate for men to make decisions for women. Women must exercise their own rights." 1

Sarojini Naidu's historical mandate: "Women must exercise their own rights," presents the key challenge of this article for our times. Eastern and western feminist rights scholars have debated whether women should or should not engage in rights strategies raising two key questions: are rights systematically exercised within a patriarchal, dominant site? Do rights constitute a multiple and relational force which may transform sites of justice?

A 1993 post-earthquake rehabilitation site in Maharashtra presents a micro-site to trace the rights between the survivors, their families, the local civil society, public, private and third sector agents within state and the international community. It is a landmark site in relation to the intersection of the international, national and local economic, political and social institutions, and actors on the ground. At this site we can trace the role of law within the personal, religious community and private legal rules and laws, the constitutional rights to life and rights to equality, and the international agreements of the World Bank and the state government in the rebuilding of lives, livelihoods and communities.

Within this micro-setting of the local community, the state and international agencies, I consider whether rights are controlled externally by a dominant force, or whether rights, can be exercised by individuals or communities at the micro-political level. Within this experience, rights seem to operate beyond a fixed framework to permeate every aspect of community lives. Rights may be understood intrinsically as a construction and that it is important to understand how rights have been constructed and how they operate to construct relations. This is the key for those who have been marginalized from mainstream rights discourse, on gender, sexuality, race, religion, caste, or any strand of 'otherness' for which alternative legal strategies may recognise the impact of rights and to re-harness, revise and reconstruct the medium and framework of rights.

\footnotetext{
${ }^{1}$ Human Rights and Human Development (Centre for Women's Development Studies, June 2000) $<$ http://hdr.undp.org/sites/default/files/indiapaper.pdf> accessed 31 October 2019.
} 
Through the theoretical framework of rights as inter-relational, I have explored elsewhere, ${ }^{2}$ the impact of the role of rights within public policy, in relation to the potential of rights discourse at the grass roots: how were the earthquake 'victims' or 'survivors' recognised at different sites of law and how did the construction of identity create agency? How were rights to housing and material needs determined and did the redistribution of resources create capacity? And where were rights accessed at different sites of law, did rights create mobility across the public/private, rural/ urban, and body/state spheres?

Audre Lorde's pioneering statement_- "For the master's tools will never dismantle the master's house"3 — has been echoed within feminist rights theories, questioning: "to the extent that feminist critique identifies law as implicated in the construction of existing gender relations, how far can it really be used to change them and do strategic attempts to use law risk reaffirming law's power?" Such questions follow Carol Smart's leading reflection:

... if we reject the idea of law as a simple tool of liberation or of oppression, and look at how it constitutes a kind of institutionalised and formalised site of power struggles - one that can provide resources for women, children and men, albeit differentially - then it is possible to acknowledge that it remains an important strategic element in political confrontations. ${ }^{5}$

Through listening to women's experience in the post-earthquake rehabilitation shelters it seemed women's identities were mainstreamed in the Maharashtra Emergency Earthquake Rehabilitation Policy (MEERP), or divided within private personal laws. Comparatively, listening to the women from the domestic violence rehabilitation group 'Voices of Experience' in England, a woman shared how in trying to access her rights to safety, welfare benefits, housing and residence for herself and her child, left her to 'choose' between an island of abuse or the "shark infested waters of the legal system." 6

Kapur and Cossman have expressed the importance of rights discourse for the women's movement stating, "law remains an important site of struggle."7 They indicate law's potential as a "site of discursive struggle," "to foster women's

\footnotetext{
2 This article draws upon my $\mathrm{PhD}$ thesis 'Reconstructing rights: an analysis of the role of rights in reconstructing gender relations in the earthquake affected area, Maharashtra, India' (2004) and a series of articles which set out each strand of analysis. See, Jane Krishnadas, 'Identities in Reconstruction: From Rights of Recognition to Reflection in the Post-Disaster Reconstruction Process'(2007) 15 Feminist Legal Studies 137; Jane Krishnadas, 'Global devaluing of Local Capacities to Care: From Rights of Redistribution to Revaluation in the Post Earthquake Reconstruction Process' (2007) 58(3) Northern Ireland Legal Quarterly 376; Jane Krishnadas, 'Relocating the Master's Domain: Social and Legal Locations of Gender from Post-Disaster to Everyday Life' (2007) 16 Social and Legal Studies 131.

${ }^{3}$ Audre Lorde, The Audre Lorde Compendium: Essays, Speeches and Journals (London Pandora 1996) 112.

${ }^{4}$ Nicola Lacey, Unspeakable Subjects: Feminist Essays in Legal and Social Theory (Hart Publishing 1998) 9.

${ }^{5}$ Carol Smart, Feminism and the Power of Law (Routledge 1989) 138 [emphasis added].

${ }^{6}$ Maria Whatton, Beaten Down, Rising Up, Standing Tall (Voices of Experience 2010).

${ }^{7}$ Ratna Kapur and Brenda Cossman, Subversive Sites (Sage 1996) 290.
} 
participation," and present a detailed critique of the potential limitations and dangers of engaging in legal strategies, which need to be negotiated and from which feminists need to "build strategies from a foundation which recognises these limitations." 8

My analysis of rights in the post-disaster reconstruction sites, explores the legal subject's interaction across the family, local government, private legislation, public legislation, government policy and international non-government organisations. Through the analysis I explore the methods by which rights exercise power to question whether rights exist as a single entity/tool, which is externally constructed and static, or whether the diverse experiences of women in the post-disaster settings progress feminist legal discourse, to transform sites of justice.

As the words of Sarojini Naidu highlight, rights may be empowering if one exercises one's own rights. Through engagement with the analysis of a range of feminist discourses, I conclude that rights may be empowering if one can exercise one's right to identity as agency, resources as capacity and location as mobility, as a three dimensional strategy to transform the framework in which one is situated. ${ }^{9}$ Over the last decade, I have actively applied learnings from South Asian feminist discourse to "reimagine our strategies"10 to inform the nationally endorsed Community Legal Outreach Collaboration, Keele (CLOCK), as a transformative framework for access to justice, ${ }^{11}$ for which the Designated Family Judge of Stoke on Trent noted: "We feel fortunate that this imaginative scheme is based locally." 12

\section{Transient spaces: an exploration of feminist rights discourse across the east and west}

From a liberalist commitment to rights as a necessary vehicle for social change, to progressive, critical, post-modern, post-colonial and materialist discourse, law has been recognised in the eastern and western feminist legal discourses as "an institutionalised formalised site of power" 13 which remains an important "site of struggle" and which "can offer spaces of resistance." 14 However the relationship between gender and rights has presented a dichotomy in feminist legal discourse whereby gender

\footnotetext{
8 Ibid 336.

9 Jane Krishnadas, 'Rights as the Intersections: Rebuilding Cultural, Material and Spatial Spheres - A Transformative Methodology' in R. Dasgupta (ed), Cultural Practices, Political Possibilities (Cambridge Scholars 2008).

10 Kapur and Cossman (n 7) 336.

11 Jane Krishnadas, 'CLOCK: 'The Community Legal Companion' as an Agent of Change: A Transformative Methodology' in Linden Thomas and others (eds), Reimagining Legal Education (Hart 2018).

12 CLOCK, 'Testimonials' (CLOCK National 'Time for Justice' Launch 2015) <https://clock.uk.net/ Pages/Testimonials $>$ accessed 31 October 2019.

13 Smart (n 5) 138.

14 Kapur and Cossman (n 7) 285.
} 
is recognised as signalling difference in the relationship of men and women whereas 'rights' under the social liberal discourse indicates equality and sameness. ${ }^{15}$

Western liberal feminism was based on the hope that extending rights to women would provide an equal position with men. However, as inequalities for women persisted, the discourse extended to question the very premise of rights by questioning the right to equality: to what and on whose terms? Marxist feminists rejected equality as within the capitalist domain, ${ }^{16}$ and radical feminism rejected the notion of equality as based on male terms. ${ }^{17}$ The interrelation between capitalist and patriarchal domination led to a dual theorist approach, either accepting both theories as dominant or presenting a fusion of both. ${ }^{18}$ Cultural feminists strove to revise the nature of rights towards an equality, which embraced and promoted female traits. ${ }^{19}$ Yet the idea that 'woman' was a category was questioned as it denied the range of alternate identifications indicating a range of oppressions other than that of patriarchy such as race, class, ethnicity, religion and sexuality. ${ }^{20}$

Voices of the South have challenged both the construction of 'women' and 'rights' as Eurocentric discourses. Third World feminism ${ }^{21}$ has sought to distinguish its standpoint from the west and to suggest that western discourse of women's rights has remained within the colonial tradition of colonizing "to characterise everything from the most evident economic and political hierarchies to the production of a particular cultural discourse about what is called the Third World." 22

Southern feminism has challenged international human rights norms as "economic imperatives of the advanced capitalist countries." ${ }^{23}$ Human rights as a discourse of formal equality has been challenged as "third world women cannot afford to embrace the notion that feminism seeks only to achieve the equal treatment of men and women, which often amounts to a formula for sharing poverty." 24

\footnotetext{
15 Jane Flax, 'Beyond Equality: gender, justice and difference' in G Bock and S James (eds), Beyond Equality and Difference: Citizenship, Feminist Politics, and Female Subjectivity (Routledge 1992).

${ }^{16}$ Martha Gimenez 'Structuralist Marxism on the "woman question"” (1978) Science and Society 301.

${ }^{17}$ Catharine MacKinnon, 'Feminism, Marxism, Method and the State: An agenda for Theory' in N. Keohane, M. Rosaldo and B. Gelpi (eds), Feminist Theory: A critique of Ideology, (University of Chicago Press 1981).

${ }^{18}$ Zillah Eisenstein, The Color of Gender: Reimaging Democracy (University of California Press 1994).

${ }^{19}$ Carol Gilligan, In A Different Voice: Psychological Theory and Women's Development, (Harvard University Press 1982).

${ }^{20}$ Lorde (n 3); Kimberle Crenshaw, 'Demarginalising the Intersection of Race and Sex: A Black Feminist Critique of Antidiscrimination Doctrine, Feminist Theory and Antiracist Politics' (1989) The University of Chicago Legal Forum.

${ }^{21}$ Gayatri Chakravorty Spivak, 'Can the Subaltern Speak?' in Patrick Williams and Laura Chrisman (eds), Colonial Discourse and Post-Colonial Theory: A Reader (Columbia University Press 1993); Nivedita Menon, 'State/Gender/Community: Citizenship in Contemporary India' (1998) 33(5) Economic and Political Weekly; Chandra Mohanty, 'Under Western Eyes' Revisited: Feminist Solidarity through Anticapitalist Struggles' Signs Journal of Women in Culture and Society (2002).

${ }^{22}$ Mohanty (n 21) 61.

${ }^{23}$ Menon (n 21).

${ }^{24}$ Cheryl Odim-Johnson, 'Common Themes, Different Contexts: Third World Women and Feminism' in Chandra Mohanty and others (eds) Third World Women: The Politics of Feminism (Indiana University Press 1991) 320 .
} 
In India, post-colonial feminism has challenged the mainstream white, western feminist discourse for satisfying its own agenda, which has failed to recognize imperialism as the key source of domination. Such a standpoint is reminiscent of the anti-colonial discourse of the nationalist movement whereby Indian men and women were "to rise and fall together" against the imperialist forces. ${ }^{25}$ During the nationalist movement, the liberal discourse of rights for 'social reform' against religious laws such as anti-sati, child marriage and widow remarriage were criticized as colluding with imperialism in the private sphere undermining the 'Indian culture' that women were to spearhead to protect India's home and hearth.

However, this third world, subaltern/post-colonial standpoint presents "a problem, especially when applied to the non-brahmanical movements by or on behalf of women; for both these had utilised the colonial law, justice and administration as major resources." 26 Hence, Rege argues that post-colonialism "ignores the relationship of gender with the pre-colonial roots of caste, gender and class domination." 27 This has become a critical concern in feminist discourses, that in the similar process of opposing colonialism to promote national identity, today's current anti-west discourse may be easily appropriated into a dominant, majoritarian 'Hindutva' position used against religious minorities. ${ }^{28}$ Hence, the premise of the feminist subject as a modern, individual and secular identity has been argued as either "a modernising project for the post-colonial elite" 29 or "inadequate to recognise the centuries of sacralised privilege to explain the existence of caste prejudices and oppression." 30

In my previous work I have set out a review of north and south feminist discourses which indicates a debate over the identification of the prioritisation of the oppression of rights and over feminist legal strategies between the material and the cultural. Fraser has outlined the predominant northern debate articulated between Young and Butler: "On one side stand the proponents of redistribution ... seek[ing] a more just allocation of resources and goods. On the other side the proponents of recognition... seek[ing] a world where assimilation to majority or dominant cultural norms is no longer the price for equal respect." 31 This so-called dichotomy is rooted in post-modern/ critical theories where "various forms of feminist cultural politics that take as their starting point gender, race, class, sexuality or coalitions among

\footnotetext{
25 Mary E. John, 'Alternative Modernities? Reservations and Women's Movement in $20^{\text {th }}$ Century India' (2000) Economic and Political Weekly.

26 Sharmilla Rege, 'Real Feminism' and Dalit Women: Scripts of Denial and Accusation' (2000) 35(6) Economic and Political Weekly.

27 Sharmilla Rege, 'Dalit Women Talk Differently: A critique of 'Difference' and Towards a Dalit Feminist Standpoint Position' (1998) 33(44) Economic and Political Weekly.

28 Ratna Kapur and Brenda Cossman, Secularism's Last Sigh? Hindutva and the (Mis)Rule of Law (Oxford University Press 1999).

29 Menon (n 21).

30 Meera Nanda, 'Hitching Dalit Modernity to Anti-Modernist Wagon' (2001) Economic and Political Weekly, 1482.

31 Nancy Fraser, 'Recognition Without Ethics?' (2001) Theory Culture and Society 21.
} 
them have increasingly displaced a systemic perspective that links the battle against women's oppression to a fight against capitalism."32

This dialect of the politics of recognition and redistribution has been reflected in southern discourse of the cultural feminism of the post-colonial tradition ${ }^{33}$ to current demands for political recognition of religious and caste minorities ${ }^{34}$ against the anti-capitalist/globalization critiques which demand the revision of the politics of redistribution towards new paradigms. ${ }^{35}$ Yet, increasingly, there is reflection on the inadequacy of the divisions. As Rege argues, "caste is cultural without ceasing to be material and Brahmanism, in its production, distribution and effect, is economic." 36 Hence, in recent eastern and western feminist discourses, the dialogue has moved to develop alternative feminist strategic goals, to bridge and interweave the questionable dialect of post-modern and material discourses towards alternative paradigms.

Ebert proposes materialist feminism "to explain how social differences, specifically gender, race, sexuality and class-have been systematically produced and continue to operate within regimes of exploitation, so that we can change them." ${ }^{37}$ Boyd encourages a change in focus from the post-modern "how we are constructed" to "how we resist or challenge dominant structures and ideologies" through law. ${ }^{38}$ Rege argues that we need "a shift of focus from difference and multiple voices to the social relations which convert difference into oppression." 39

The search for alternatives has moved beyond the discourse of cultural and materialist analysis to a holistic analysis of the construction of the subject as interacting with the outside world. Alcoff's work towards developing a new woman draws on Lauretis' work of woman constructed through her subjectivity, interactions and experiences of the outside world to become "multiple and shifting." 40 Alcoff progresses this towards a "concept of positionality" 41 whereby "the external position of a pawn on a chessboard is considered safe or dangerous, powerful or weak,

\footnotetext{
32 Rosemary Hennessy and Chrys Ingraham, Materialist Feminism a Reader in Class, Difference and Women's Lives (1997).

33 Spivak (n 21).

34 Jana Everett, “All the Women Were Hindu and All the Muslims Were Men': State, Identity Politics and Gender' (1951) 36(23) Economics and Political Weekly; Meena Nanda, 'Representation for Women: Should Feminists Support Quotas?' (2000) 35(33) Economic and Political Weekly; Wandana Sonalkar, 'An Agenda for Gender Politics' (1999) 34(1) Economic and Political Weekly 24.

35 Mohanty (n 23); G. Sen and C. Grown, Development, crises and alternative visions: third world women's perspectives for Development Alternatives with Women for a New Era (1988); Chhaya Datar, 'NonBrahmin Renderings of Feminism in Maharashtra: Is it a more Emancipatory Force?' (1999) 34 (41) Economic and Political Weekly 2964.

36 Rege (n 26) 495.

37 Teresa Ebert, Ludic Feminism and After Postmodernism: Desire and Labor in Late Capitalism (The University of Michigan Press 1996) 7.

38 Susan B. Boyd, 'Family, Law and Sexuality: Feminist Engagements' (1999) 8(3) Social and Legal Studies 373.

39 Rege (n 27).

40 Linda Alcoff, 'Cultural Feminism Versus Post-Structuralism: The Identity Crisis in Feminist Theory' (1988) 13(3) Signs: Journal of Women in Culture and Society 425.

41 Ibid 428 .
} 
according to its relation to other chess pieces." 42 Alcoff summarises the external as the "objective economic conditions, cultural and political institutions and ideologies, and so on." 43 However, within this setting of the earthquake reconstruction process, I seek to extend the 'external' to a physical external of place. I draw upon post-colonial discourses of place as representing the "hearth and home" 44 to engage Massey's question of the very "authenticity" of "a place called home" of place." 46

In this article, I trace the relation of location to the issue of standpoints. ${ }^{47}$ South Asian discourse argues that "western social sciences that inform our work may prove to be irrelevant to our concerns and completely divorced from women at the grassroots." 48 This reveals the importance of place, the 'grassroots', as an identification of location, a place. I argue that the position of 'third world', 'post-colonial', 'grassroots', is a constituent of the rights regime. Though calls for an 'indigenous' social science critique reflect the inauthenticity of place as to never truly be indigenous in relation to observer studies. Kalpagam's call for the 'local' is representative of the local and global discourse of grassroots feminism. ${ }^{49}$ This return to the local is indicative of Smart's cautionary note, that "we must never forget that women discursively construct themselves... If we do forget this, we risk disempowering 'women' and over inflating the power of more organised discourses." ${ }^{, 5}$

Following the movement within eastern and western feminist discourses to seek alternatives, I propose to analyse the construction of gender in the earthquake affected area through the construction of rights from state policy, legislation to the non-formal spheres. Through this analysis, I seek to progress the concept of recognition toward reflections, redistribution to reclamation and location to transition. I put forward a holistic view of the integral nature of the constituents of rights to reconstruct the rights regime through modes of empowerment.

\footnotetext{
42 Ibid 433.

43 Ibid.

44 Partha Chatterjee, The Nation and its Fragments: Colonial and Postcolonial Histories (Princeton University Press 1993); Himani Bannerji, 'Projects of Hegemony: Towards a critique of Subaltern Studies' 'Resolution of the Women's Question' (2000) 35(11) Economic and Political Weekly 902; Aamir Mufti and Ella Shohat, 'Introduction' in Anne McClintock and others (eds), Dangerous Liaisons: Gender, Nation and Postcolonial Perspectives (University of Minnesota Press 1997).

45 Doreen Massey, Space, Place and Gender (University of Minnesota Press 1994) 157.

46 Ibid 146.

47 Sandra Harding, Feminism and Methodology (Indiana University Press 1997).

48 U. Kalpagam, 'Perspectives for a Grassroots Feminist Theory' (2002) 37(47) Economic and Political Weekly.

49 Mohanty (n 21); Marianne H Marchand and Anne Runyan, Gender and Global Restructuring: Sightings, Sites and Resistances (Routledge 2000); Vandana Shiva and Maria Mies, Ecofeminism (Zed Books 1993).

50 Carol Smart, Feminism and the Power of Law (Routledge 1995).
} 


\section{A transformative rights methodology}

As set out in my earlier research,${ }^{51}$ the centring of women's experiences in the rehabilitation process provided a critical lens to analyse the broader impact of feminist legal rights strategies for women's experience in the private sphere. Kimberley Crenshaw argues:

If their efforts instead began with addressing the needs and problems of those who are most disadvantaged and with restructuring and remaking the world where necessary, then placing those who currently are marginalised in the centre is the most effective way to resist efforts to compartmentalise experiences and undermine political collective action. ${ }^{52}$

From the earthquake shelters of Latur, India, to the women's domestic violence refuge in Stoke, England, my centre-point of relations was with the women survivors. It is from this centre-point that I engaged in a process of examining women's relationship with the reconstruction process and position in the reconstructed society, in relation to the post-earthquake affected area, and the post-domestic violence reconstruction of everyday life.

This process of understanding the relationship between the individual and society is reflected in gender and disaster discourse. As Enarson and Morrow note: "paradoxically we learn most about ourselves and the physical, social and political environments we have constructed when our taken-for-granted lives are disrupted." 53 It is this same point of critical reflection, or as Friere terms "conscientization," which marks the first step to empowerment as people become "aware both of the socio-cultural reality which shapes their lives and of their capacity to transform that reality." 54

As I write, I am very conscious that my presentation of the post-disaster reconstruction process, may draw and indeed warrant a similar critique. To profess to contain the huge, diverse complex and often private experiences of the earthquake affected community or domestic violence survivors, within a window, a scene, a snapshot, a chapter of words for public view_and that too, through my 'western eyes', and, or my 'academic' pen - draws immediate concerns of standpoints, textual appropriations and embedding the private and public spheres raised in feminist writings. ${ }^{55}$

\footnotetext{
${ }^{51}$ Krishnadas (n 9).

${ }^{52}$ Crenshaw (n 20).

${ }^{53}$ Elaine Enarson and Betty Morrow, The Gendered Terrain of Disaster Through Women's Eyes (Praegar 1998) 1.

${ }^{54}$ Paulo Freire, 'Cultural Action For Freedom' (1970) Harvard Educational Review 51.

55 Dorothy Smith, Texts, Facts and Femininity: Exploring the Relations of Ruling (Routledge 1990); Spivak (n 22); Chandra T Mohanty and Jacqui Alexander, Feminist Genealogies, Colonial Legacies, Democratic Futures (Routledge 1997); Marjorie DeVault, Liberating Method: Feminism and Social Research (Temple University Press 1999); Anne Opie, 'Qualitative Research, Appropriation of the 'Other' and Empowerment' (1992) Feminist Review 52; Jane Ribbens and Rosalind Edwards, Feminist Dilemmas in Qualitative Research, Public Knowledge and Private Lives (Sage Publications 1998).
} 
Hence just as I have drawn upon Dorothy Smith's analysis of "relations of ruling" 56 to interrogate sites of justice, I choose the same criteria to question my engagement within the post-disaster reconstruction process. I seek to highlight the reconstruction process - rather than a fixed scene-as a changing, dynamic process which demands a materialist analysis of peoples' lives; not only "to be open to how the terrain under analysis is actually put together," ${ }^{57}$ but to how it is changing, and the transformative potentials within. Smith grounded the feminist standpoint as "women's standpoint as distinctive in situating the experiencing subject in the actual local particularities of her everyday/every night world, where her bodily existence locates her consciousness." 58

From this feminist legal researchers have developed the concept of specific and different standpoints to reveal their cultural, sexual, professional and personal perspectives. ${ }^{59}$ This standpoint, in my experience, is necessarily changing according to human relations, contexts and the very process of research. This process of change is directly linked with the fact that we are listening to the 'subjects' who in fact become active agents of both our thoughts and perspectives. Hence much of the perspective and drive within my research is sourced from the changing and diverse relations with the women of the villages where I lived and worked, and in my current research with the women from the refuge, who helped create agency, capacity and mobility within myself.

In order to illustrate the changing standpoints, I first introduced my role as an 'outsider', an observer and as an actor in the rehabilitation process. In 1993, I arrived as a volunteer and joined the relief team in Nandurga village, where I lived and worked for two years in association with the Catholic Hospital Association of India. For the next two years, I moved to a village 4 kilometres away and was employed as Deputy Manager of the Oxfam housing project in Lohata village. I, therefore, positioned myself firmly within the text as to clearly expose my position as an 'outsider' to the region and therefore to contextualise my observations as an outsider's perception and a subjective understanding of what I have seen and experienced. On visiting the domestic violence refuge, I introduced my role as a teacher and researcher, but joined the coffee mornings in a personal capacity, as a woman and a friend.

My access and presence within the area can attract Said's critique of "positional superiority," where "the scientist, the scholar, the missionary was in, or thought about the Orient because he could be there without very little resistance on the Orient's part. ${ }^{60}$ With this in mind, I have also traced the personal element of how I

\footnotetext{
56 Ibid Smith 6.

57 Ibid.

58 Dorothy E Smith, 'Writing Women's Experience into Social Science' (1991) 1(1) Feminism and Psychology 158.

59 R. Kapur and B. Cossman, 'Trespass, Impasse, Collaboration: Doing Research On Women's Rights in India' (1991) 2(2) The Journal of Human Justice; Mohanty (n 22); DeVault (n 56); Ann Oakley, 'Interviewing women: A contradiction in Terms" in Roberts. H (ed) Doing Feminist Research (Routledge 1981).

60 Edward Said, 'From Orientalism' in Williams Patrick and Chrisman Laura (eds.) Colonial Discourse and Post-Colonial Theory: A Reader (Columbia University Press 1993).
} 
entered the area through building trust and relations within the villages. I decided to stay in the villages, to become the longest standing 'outsider' to live in the area. Hence, though physically white, geographically western and socially 'independent', I had feelings and bonding with the families of the community. With them I shared experiences of living in the earthquake shelters through the heat and storms, shared food, wore local attire, adopted gestures and manners and learnt to speak the local language. I shared personal experiences and day-to-day life, more than the transient 'outside' organisations which came and left on a professional footing. Similarly, through my work with Voices of Experience, I attended the coffee mornings, workshops, day trips with the children and found my own experiences reflected in their experiences to share within the 'safe space'.

I then applied the question 'for what?' to consider my purpose in the area. I entered the earthquake affected region, not with an intended research project but as a volunteer relief worker, initially for an expected period of two weeks, yet which extended to four years as I stayed to facilitate the reconstruction process. On arrival, I understood that much of the emergency work had been done, relief materials were in excess and that the community shared a desire to get on with their lives. Hence many of the medical and social work 'volunteers' were returning to their professions. I chose to stay as I had one resource which was limited amidst the professionals, and that was 'time'. Similarly, my work with the refuge in 2011, has continued through the co-creation of CLOCK, which is still ticking for access to justice today.

From the villages to the refuge, I was invigorated by the women's determination and to listen and voice their aspirations. I stayed to volunteer as a community development facilitator particularly working with the woman of the villages, and later on return to England, as a regular member of Voices of Experience. In Latur, my role was to facilitate dialogue with the women of the villages through house to house visits, village meetings which we held on a weekly basis and then weekend workshops which sought to bring women from different villages together. At the refuge, my role was to listen and contextualise and voice the experiences within the wider legal process. As such my 'research' began as a process of listening and promoting women's dialogue, to be heard within the non-government and government social and legal policy reform process (to inform the Right to Justice Report, 2015, and the Ministry of Justice Legal Aid, Sentencing and Punishment of Offenders Act, PostImplementation Reform, 2018).

By revealing my position, perspective and purpose within the process, I initially proposed a "significant research methodology," 61 one for a purpose, a "political model of feminist research practice which valorises research leading to collective social action," ${ }^{2}$ to become a 'transformative methodology' for transforming sites of justice.

As a live-in observer, ${ }^{63}$ I witnessed the four-year rehabilitation process on a day to day basis. As a community development worker, I was privy to information on

\footnotetext{
61 Opie (n 55) 65.

62 Ibid 66.

63 Jane Krishnadas $\mathrm{PhD}$, 'Reconstructing rights: an analysis of the role of rights in reconstructing gender relations in the earthquake affected area, Maharashtra, India' (2004) 60.
} 
wider statistical and objective information on the area, and perspectives of other social workers. Further, I was interacting with other organisations in the area and therefore was able to collate information on their activities.

My diary entries ${ }^{64}$ were reflections upon the series of observations and interactions with the community during the process. The house visits, women's meetings and women's workshops were constructed as a forum for women to specifically engage in reflection and action on the rehabilitation process. It is from these locations which I seek to project the data, the perspectives and engagements of women, as a relational process with legal actors at each level of the system to become a transformative methodology for access to justice.

The research methods drew upon engagement with women of the community through house-to-house visits in the villages to the construction of women's meetings in the seven neighbouring villages on weekly basis. Such meetings were voluntary meetings whereby the women who attended the meeting had clearly chosen to attend for a variety of reasons, and the attendance of such meetings changed in number and in caste and religious dimensions as the rehabilitation process progressed. Two elected representatives from each of seven villages attended weekend workshops to address shared issues across different castes, religions and locations. At the onset, I guided the agenda of discussion whereas over a period of the women set their own agenda in response to the rehabilitation process, which guided my own reflections and understanding of rights as inter-relational. This method informed the co-creation of CLOCK, where the women of Voices of Experience became members of the Steering Committee, to guide the co-creation of the Community Legal Companion role to listen and to assist each litigant in person to voice their own experience in the legal process.

\section{A transformative rights analysis}

Through understanding the post-disaster reconstruction sites as relational, I explore the impact of the role of rights within public policy, in relation to the potential of rights discourse at the grass roots; how were the earthquake 'victims' or 'survivors' recognized at different sites of law and how did the construction of identity create agency? How were rights to housing and material needs determined and did the redistribution of resources create capacity? And where were rights accessed at different sites of law, did rights create mobility across the public/private, rural/urban, and body/state spheres?

This analysis of rights in the post reconstruction sites, as an umbrella of public policy, private legislation and the non-formal sphere of community relations, challenges whether rights exist as a single entity or tool, within an externally constructed and static framework, or inter-relational, fluid and transformative sties of justice.

64 Ibid. 
Listening to the voices of those seeking to exercise their rights, the rights bearers, challenged the notion of the individual and autonomous legal subject, but rather the rights bearer as relational and interdependent upon the legal actors around them in order to enact agency, create capacity and mobility to transform their position within the rights regime.

The analysis and understanding of rights operating at different levels and between different actors within the rights regime, has informed the design of CLOCK, the Community Legal Outreach Collaboration Keele. CLOCK was initiated in response to listening to women in the post-domestic violence refuge, who met to discuss how to rebuild their lives, seeking safe housing, welfare support and navigating the public and private court system to protect their families following the 'legal aid crisis'. ${ }^{65}$ Drawing upon the Voices of Experience of women of the post-disaster rehabilitation process, CLOCK developed a multi-agency and relational framework to support litigants in person, through the role of law students as Community Legal Companions to signpost to mediators, charitable sector, legal professionals and the judiciary, as a bridge to promote the transformation from victims to survivors, beneficiaries to contributors and from objects to agents of change. The design of CLOCK was focused upon the three strands of rights analysis: to create agency, by centring women's voices and experience through the legal process, to create capacity through connecting legal actors and revaluing resources to reform legal aid, and to create mobility through sharing the voices and experience at different levels of local to national policy and legal reform. CLOCK has trained law students as Community Legal Companions to assist more than 4,000 people since the significant withdrawal of legal aid, has submitted evidence to inform the reform of legal aid, and has received a national award for the outstanding contribution to access to justice in England and Wales, and has shared good practice through the All India Access to Justice Strategy $^{66}$ to train law students to assist the survivors of the Odisha Cyclone and Kerala Floods in 2018-19. ${ }^{67}$

\subsection{Victims or survivors: do rights construct identity/ create agency?}

To understand law as actively constructing identity, it is important to examine the construction of women's identity within their own self-reflection, or in relation to how they are identified by the state. The experience of the Latur rehabilitation process marked a period of externally planned and implemented change at a significant time of domestic upheaval. Hence the external period of fixed change marked the modernisation process and reinforcement of community identity in this devastated private and domestic sphere.

My field work was set in the earthquake affected area, following the devastation of 61 villages and death of more than 8,000 people. The earthquake devastated

\footnotetext{
65 Sarah Moore and Alex Newbury, Legal Aid in Crisis (Policy Press 2017)

66 Krishnadas (n 9).

67 National Law Schools of Odisha and Cochin, All India Access to Justice Strategy Report (2019), nominated lead, Assoc Prof Krishnadas Sukumaran.
} 
the social fabric leaving 445 widows, 932 widowers and 1512 orphans. ${ }^{6}$ At this time of domestic upheaval, I witnessed how the post-earthquake rehabilitation process initiated an external and imposed modernisation process of reconstructing the community.

The relocation of villages in adjacent plots created small townships. The community housing cluster arrangements within villages developed into houses placed in rows. The joint family structure was divided into individual nuclear housing units. The construction process demanded an increase in local labourers recruiting unskilled women and working children. The construction work was taken up by women and girls, providing a new mobility, interaction and exposure outside of their traditional household activities.

At such time the sexuality of women and particularly the sexuality of widows was seen to threaten the traditional community structures. Hence in reaction to the forced and external modernisation process, the traditional community family structures were defended and preserved through the tightening of community ties and laws and the construction of women's identity in the public policy as 'citizens' and in the private litigation through personal laws defining women by their familial and religious identities.

Over the four years of women's meetings, there was a noticeable shift from the open meetings including women of all different backgrounds seeking immediate support and relief, to the reduction of participants, as women became more constrained within the home. Within the process of 'development' women from minority communities in Latur felt that their difference was a status of backwardness compared to the nominated women of higher caste, who would attend the women's group meetings as a representative of the constructed 'women' beneficiaries. Hence, though the modernisation process was based on liberal, secular values within the public sphere, the private sphere was accorded to the religious and caste community restrictions imposed in order to preserve and protect the women as markers of their tradition and identity. Hence whilst the development process was initiated within the public sphere, a policy of non-intervention was accorded in the private domestic sphere marking the overriding patriarchal approach of the modernisation process.

The discourse of women as citizens has been articulated as "effacing ascriptive hierarchical inequalities and masking differences of culture, caste, gender to make such differences irrelevant for the exercise and enjoyment of rights of citizens." 69 However feminist legal discourse has questioned the feasibility of the contextfree citizen as Mukhopadyhay's analysis asks: "why was it so difficult to actualise women's rights as citizens? Why was it next to impossible to disentangle a woman's

\footnotetext{
68 S. Parasuraman, 'Organisation and Administration of Relief and Rehabilitation Following Marathwada Earthquake, 1993' (Centre for Research on the Epidemiology of Disasters-Tata Institute of Social Sciences 1995).

69 Ritu Menon, “Reproducing the Legitimate Community': Secularity, Sexuality and the State in Postpartition India' in Patricia Jeffery and Amrita Basu (eds), Appropriating Gender: Women's Activism and Politicized Religion in South Asia (Routledge 1998).
} 
identity as a subject/citizen imbued with rights from that of her identity as daughter, sister, wife and mother?"70

A range of cultural feminism has questioned the desirability of denying the female context in citizenship discourse. Further minority groups have provided a critique of the homogenising process of citizenship, which has meant the foregoing of community identities towards the mainstreaming of 'neutral citizenship'. Chatterjee has presented a detailed analysis of the implications of the colonial period on women. He notes how the project of "colonialism also saw itself as performing a civilising mission" whereby the figure of the Indian woman was transformed into a "sign of the inherently oppressive and unfree nature of the entire cultural tradition of a country." 71 Chatterjee notes how in response the nationalist paradigm supplied an ideological principle of selection- "an ideological sieve" - to create the new traditional woman. The new Indian woman of the nationalist process represents the conflicting demands of women as an individual and liberated citizen and as the protector and preserver of national community religious identity. ${ }^{72}$

In this development process a mainstreaming of identities took place in accordance with dominant Hindu identity. As Menon notes: "definitions of modern take place in a political field where certain identities are privileged even while equality is promised and other subordinated."73 There developed an inclusive notion of citizenship gradually bringing into the fold various marginalised sections of society i.e. muslim, low caste, tribal. Anupama Roy refers to this as the "integrative function" of the unmarked equal citizen, ${ }^{74}$ where the "[p]ower to disassociate oneself form the context is differentially available to a large mass of citizens and that the forging of sameness often serves to make repression for those who do not belong to the dominant culture." 75

Feminists have appealed to post-structural legal discourse to legitimise and realise struggles beyond inclusion, to be identified in their own right. Kimberley Crenshaw has discussed this in terms of different and intersecting standpoints i.e. as a black woman. ${ }^{76}$ Crenshaw seeks to extend the single axis of discrimination to address the multiple sites of discrimination. She concludes that the "the goal of this activity should be to facilitate the inclusion of marginalised groups for whom it can be said: When they enter, we all enter."77

The Latur experience raises the question of what type of reconstructed society were the women entering into? The women were either identified as 'victims' to be rehoused within the externally designed unit houses and new townships, or if they

\footnotetext{
70 Maitrayee Mukhopadhyay, Legally Dispossessed: Gender Identity and the Process of Law (Stree 1998).

71 Chatterjee (n 44) 118.

72 Himani Bannerji, 'Projects of Hegemony: Towards a critique of Subaltern Studies' "Resolution of the Women's Question"” (2000) 35(11) Economic and Political Weekly.

73 R. Menon (n 69).

74 Anupama Roy, 'Community, Women Citizens and a Women's Politics' (2001) 36(17) Economic and Political Weekly.

75 Ibid 1441.

76 Crenshaw (n 20).

77 Ibid 167.
} 
stepped outside of the family unit, they would be identified within their personal laws according to their religious and familial status. Beyond the concept of intersectionality, ${ }^{78}$ and the demands that we understand the multiple axis of discriminations on race, caste and gender, it is important to understand the different changing contexts of oppression. Joseph refers to an approach in the study of culture where "individuality is conceived as polyvocal with the possibility of many identities derived from the various subject locations of the individual."79 Fixed identities hence limit the identification of the sources of oppression. The legal labelling of woman "thwarts women's potential to mobilise across the communal divide and to challenge both the sexism in their daily lives and sexism and communalism engrained in the provision of public services." 80

The reduction of women's identity into the fixed construct of the legal subject limited the plurality and common ground of women's identity to fight against the systematic oppression of women in their different contexts. Comparatively, the women within the domestic violence refuge, who drew upon each other's shared experiences for support, were either identified as 'victims' within the domestic violence refuge or once they stepped outside, they were fragmented as individual legal subjects when faced with private legal proceedings from ex-partners who now sought contact with the children. In both scenarios, the fragmentation of shared experiences created a vulnerability as a legal subject, from which to challenge the state-constructed dominant familial ideology.

\section{Beneficiaries or contributors: How did the reconstruction of resources create capacity?}

\section{Kapur and Cossman identify}

two different manifestations of familial ideology of moral and economic regulation; moral regulation refers to where women who live up to the ideals of motherhood and womanhood are accorded some protection, and those who fail to measure up are penalised... and economic regulation, refers to the ways in which the assumption of economic dependency contained within familial ideology and the sexual division of labour operates in women's lives. ${ }^{81}$

Within the villages in which I worked and observed, ${ }^{82}$ the traditional familial ideology of the system of the male joint family was in the minority. Rather the families lived as communities to the point where it was difficult to ascertain the exact immediate family relations. A key point in contrast to the patriarchal and joint family as

\footnotetext{
78 Ibid.

79 Ibid 14.

${ }^{80}$ Patricia Jeffery and Roger Jeffery, 'Gender, Community and the Local State in Bijnor, India', Appropriating Gender, Women's Activism and Politicised Religion in South Asia (Routledge 1998) 140.

81 Kapur and Cossman (n 7) 97.

82 Krishnadas (n 63) 111.
} 
the dominant family structure was that their maternal families took in women who were unmarried, deserted, destitute or widowed. This was more so after the earthquake where the make-shift shelters were shared by the families and the communities embraced those orphaned and widowed to try and restore the functioning of family. However, rather than the dominant patriarchal joint family structure it was the maternal family which embraced and took in the orphans and widows.

Many households in the villages had female-headed households where the husband had migrated to the cities for work, were employed in the military or had passed away. In those instances, the women were the head of the household and often were engaged in paid employment in addition to carrying out household tasks. Particularly in the poorer communities the women went out to work in the fields and on the construction sites and mostly took the children with them, if old enough to work, or as babies, lying in hammocks tied between the trees. Where there were small landholdings women were involved in subsistence farming within the family and earnings in kind such as the home produce.

Kapur and Cossman affirm that "there is no question of the enormous and profound difference in familial forms and experiences in India and note that many women may in fact be the sole wage earner within the household. Studies at that time found that over 50 per cent of rural women work as agricultural labourers." 83 However, in terms of legal discourse, they reaffirm that it may still be important to speak of the ideologically dominant family and advise the necessity of feminist legal strategies to acknowledge and understand the judicial dominant discourse as a fact rather than deconstructing the dominant discourse.

This familial ideology was translated into the earthquake area, whereby women were caught between the familial ideology and cultural practice. Though the Hindu Succession Act 1956 gave women rights in the marital property this reinforced the customary practice to ostracise the widow from the husband's house. Further, the granting of such rights within the patrilineal dominant familial ideology refused to provide her any rights within the woman's maternal family. In the post-earthquake situation, the joint property had been devastated and instead individual nuclear units were allocated to only the sons of the family. This, therefore, left no provision, nor space to be accommodated within the maternal family's home. This situation meant that the maternal home could no longer accommodate the destitute or widowed daughter.

This was evident during my field research in Laur, where in Hassalgaan village, Rupa was returned at her mother's doorstep by her husband, due to her doubted fidelity. ${ }^{84}$ Rupa's maternal family was ready to take care of the daughter, however, there was no legal provision to obtain maintenance from the husband's family within the maternal home. The Maharashtra Earthquake Emergency Rehabilitation Project (MEERP) did not include the returned daughters within the allocated houses, and familial ideology was so strong that it was engrained even in the policy

\footnotetext{
83 Kapur and Cossman (n 7) 93.

${ }^{84}$ Jane Krishnadas 'Identities in Reconstruction: From Rights of Recognition to Reflection in Post-Disaster Reconstruction Processes’, (2007) Feminist Legal Studies 158.
} 
of NGOs which only provided houses for the sons and not for the daughters. ${ }^{85}$ The personal laws only gave recourse to obtain maintenance against the husband's family if she returned to the husband's house, where she had faced rejection and mental and physical torture. Women who approached the courts for remedies were therefore forced back into the dominant familial ideology.

Twenty years later during my research with Voices of Experience, women in the domestic violence refuge ${ }^{86}$ explained that where their family homes were owned by the husband/partner either in their sole or joint names, they were unable to evict the husband due to his property rights, and as there was no room to stay in their maternal home, they were forced to flee to live in refuges often located several miles away from their work place, maternal family and friends, and children's schools, leading to isolation and vulnerability, or stay to face the violence within the martial household. Hence, the priority of their husband's or partner's property rights were at the cost of women's caregiving contributions reducing their capacity to reconstruct their lives.

\section{Why doesn't she leave? How were women located within the legal system? Was the position transformative?}

Within the analysis so far, I have indicated that the mainstreaming of fluid and changing identities and practices into the fixed constructs of legal subjects and legislation has created an axis between the state and the community, and modernity and culture, where women have no place. In this final section, I analyse the mainstreaming of traditional and changing methods of dispute resolution at the community level to the modern legal system and question the impact on women. Marc Galanter has traced the transformation of the indigenous, traditional and local legal systems towards the mainstreaming of rights. In response to the British, liberal and individualistic principles of a modern legal system, fluid and cross-community dispute resolutions were made rigid on the basis of religious legal practice. The modern adversarial basis of law in women's experience places her in a diametrically opposed identity to her partner or her community. The litigation process may be seen as a model of the antagonism of the fixed identities of the individual versus the community identity, which has been constructed in the modernisation of sites of justice.

Galanter writes:

In contemporary India as in other complex societies there are myriad agencies for making rules and settling disputes which lie outside the legal system as defined as governmental complex of institutions, roles and rules. Many matters

85 Oxfam, Latur Office, Field Reports, 1995-1997.

86 Whatton (n 6). 
are regulated by traditional legal norms; tribunals of the traditional type continue to function in many areas and among many groups. ${ }^{87}$

In Latur, customary law was practiced as per the region, religion or caste. Issues were settled within and between the community. The muslim community had a structured system of problem resolving due to their historical role in the area as tax collectors and administrators and the religious standing of the laws. ${ }^{88}$ The Banjara tribal community had a history of their own legal system, which had now been modernized to settle disputes within and outside their community. ${ }^{89}$ The Hindu community settled disputes according to their caste leaders. Inter-religious caste disputes exercised legal practice through the village panchayats and in cases of severity the case was taken to the local court system. ${ }^{90}$. Within all communities, disputes in the domestic sphere, and particularly relationships between husband and wife and within the family, traditionally 'problems' or disputes were settled within the immediate family the extended family and in grave situations the community.

Traditional customary practice was based on the premise of reconciliation based on community negotiations whereby the remedy sought is to resolve the problems. In Latur this process was initiated through negotiation with the parties and the elders of their family and community. However, it is evident that the fluid systems of problem resolving within the community have been formalised and disciplined into religious systems of law.

In 1993, the Muslim Personal Law Board introduced a provision for establishing Shariat courts throughout the country. Such a move was termed 'regressive' by reformers such as Asghar Ali, who suggest that the Shariat courts will be "dominated by those qazis who are quite conservative and apply Shariat in a rigid way without understanding the changed context and the greater awareness among women today of their rights." ${ }^{91}$ Similarly, the informal and local methods of community settlement were 'reformed' by the Hindu legal practice which exercised law according to Brahmanical structures of caste hierarchy and this was adopted into the modern legal system. ${ }^{92}$ The local methods of problem resolving and reconciliation within the family and community structures were mainstreamed into the adversarial system of law. Flavia Agnes indicates that

[w]omen approach an agency for help because they have problems which need solutions. Since there are no laws to protect a women' rights within marriage, it is generally resumed by advocates and activists that a petition for divorce is the only answer to the women's problem. Hence without the woman's knowledge, a solution to a marital problem gets transformed into a petition for

\footnotetext{
87 Marc Galanter, Law and Society in Modern India (Oxford University Press 1992).

88 Krishnadas (n 63).

89 Ibid 230.

90 Ibid 232.

91 Asghar Ali (Frontline, June 3rd 1994) 81.

92 Galanter (n 87).
} 
divorce. Once the divorce is granted the woman loses her rights to reside in the matrimonial home, her access to her husband's property, earnings etc. ${ }^{93}$

The modern legal system has been presented in feminist legal discourse as to provide redress to the woman where her own family and community oppose her. The 'reform' of the traditional community resolutions has been dominated by a system of law based on patriarchal and hierarchical structures of caste and other power structures. Hence, the concept of the unmarked abstract citizen with legal rights was promoted as liberal, equal and secular justice.

Yet, as witnessed in the field research, the case study of Rupa indicated the emptiness of the outside world; the hardship of the social, economic and cultural survival outside compared to the support systems within. For Rupa, once she entered into litigation, she was ousted from the community. Rupa's experience of the litigation process and remarriage depended on the support from the community. Her husband who had forced her abortion at seven months and then deserted her on the doorstep of her parent's home, had stated in court that the marriage to Rupa had never taken place and that he had now (re)-married. The procedure of solemnising a hindu marriage at one level remained Brahmanical. But at the other level, the Code validated customary rituals and ceremonies. The Hindu Code Bill neither clearly laid down the procedure solemnising the hindu marriage nor made the registration of marriages compulsory. Due to the courts adopting a rigid view that only saptapadi and vivahahamo are valid marriage ceremonies, the marriage was not accepted. If ceremonies could not be proved, then the marriage was not valid.

Rupa depended on the community to be witness to the valid marriage conducted in the village, but no one came forward from the Brahmanical community to which she belonged, to support her for fear of penalisation under the Child Marriage Restraint Act, 1929. Hence the first marriage could not be proved and Rupa had to face rejection from the community due to the social stigma of the marriage, abortion and litigation, and equally, the rejection by the courts. This is a clear example of the patriarchal construction of both Articles 14 and 25 as marginalizing and deconstructing women's identity and very survival. Once in litigation a woman has to assert her rights within the conflict of individual citizen versus community identity, which gives little scope on the axis of Articles 14 and Article 25 for her position as a woman. ${ }^{94}$

Flavia Agnes' summary of the day-to-day marginalisation of women from the legal process in the early 1990s was echoed in the discussion groups with women from Voices of Experience in 2011 to date.

Once a woman has decided to litigate against her husband, family, community it is often on behalf of the state. Police registered cases were taken up by public prosecution or within the civil sphere controlled by the arms of the state such as the lawyers, etc. It therefore placed women in the hands of the main-

\footnotetext{
93 Flavia Agnes, State, Gender and the Rhetoric of Law Reform (Research Centre for Women's Studies 1995) 188.

94 Krishnadas (n 63).
} 
stream system. Firstly, the legal process was alien and unfamiliar. The women were vulnerable due to their legal ignorance and illiteracy. Lawyers were not trusted due to the experience of corruption. The police were feared and practically the court process was felt out of bounds due to the financial constraints and limited mobility. ${ }^{95}$

Twenty years on, in England and Wales, the public/private dichotomy of pursuing remedies in the family and criminal law has been echoed by legal scholars, as despite the rise of the disclosure of domestic violence, applications for non-molestation orders and occupation orders are declining. ${ }^{96}$ This has since been amplified by the significant withdrawal of legal aid, resulting in a state barrier to access to justice.

The 2013 legal aid cuts left victims of domestic violence stranded in abusive relationships. Women, who make up the overwhelming majority of those facing domestic violence, have borne the brunt of this cruel cut. The stark reality is that without legal representation, many find themselves trapped in dangerous situations that often escalate. ${ }^{97}$

It was Sharon's question- "Whether to leave the island of abuse or enter the shark infested waters" 98 - which sparked the development of CLOCK, the Community Legal Outreach Collaboration, Keele, as a holistic and inter-relational mechanism, to reimagine legal strategies to bridge the private and public sphere, to transform sites of justice.

\section{Conclusion: How may feminist legal strategies be transformative?}

To date, feminist legal strategies have advocated the recognition of the dominant ideologies to inform legal strategies. The centring of women's experience, has provided a lens to deconstruct the very structures on which these ideologies are based. This analysis reveals that the very foundation of the legal subject, based on homogenous and universal standards of equality and secularism, cannot be distinguished from the multiple nature of identity and multiple systems of oppression, for which the lens is not only to be centred upon the individual, but in relation to the system in which the individual is situated and interacts at each layer from family, community and the state.

The rehabilitation period, whether in terms of the earthquake reconstruction or survivors of domestic violence, exposes the crucial need to move beyond the fixed patriarchal constructs of individualism versus community, modern versus tradition where the liberal and secular discourse of citizenship as a premise for entry to

\footnotetext{
95 Agnes (n 93).

96 Many Burton, 'Civil law remedies for domestic violence: why are applications for non-molestation orders declining?' (2009) 31(2) Journal of Social Welfare \& Family Law 109.

97 Estelle du Boulay, 'A cut too far: LASPO and the survivors of domestic violence', (2017) Legal Voice.

98 Krishnadas (n 11).
} 
the legal system, has in practice reinforced the traditional patriarchal and capitalist structures of the public and private domains of law.

Through tracing women's lived experiences I suggest that the individual woman's experience provides the knowledge to resist the construction of women's identity and needs by the legal system, and present her issue in all its complexity of the context in which it stands. It is the language of rights, which positions women as individuals within the private or public sphere, or as Sharon articulates within the "island of abuse, or shark infested waters," 99 which restricts mobility within an often polarised and adversarial system. The complexity of women's experiences fragments the linear construction of identity and needs as a static construction, but rather as inter-dependent, transient and transformative.

It is from this point of crisis that provides the key to CLOCK, the Community Legal Outreach Collaboration, Keele, ${ }^{100}$ which centres women's experience to reconstruct the rights framework with a multitude of actors, from the academic, professional, judicial and charitable sectors. Together we have created an inter-relational network to prioritise the legal subject, as an agent of change, and work in collaboration with legal actors to create a bridge across the private and public spheres to transform pathways and sites of justice. CLOCK has now been cascaded across 12 university law schools operating in the respective courts and has assisted more than 4,000 litigants in person across public and private law matters. In tracing the thesis of CLOCK back to the feminist legal discourses in India, CLOCK has shared good practice with the All India Access to Justice Strategy, working with university law schools as a bridge between the individual and the legal system in times of crisis to transform sites of justice.

Open Access This article is distributed under the terms of the Creative Commons Attribution 4.0 International License (http://creativecommons.org/licenses/by/4.0/), which permits unrestricted use, distribution, and reproduction in any medium, provided you give appropriate credit to the original author(s) and the source, provide a link to the Creative Commons license, and indicate if changes were made.

Publisher's Note Springer Nature remains neutral with regard to jurisdictional claims in published maps and institutional affiliations.

\section{Affiliations}

\section{Jane Krishnadas ${ }^{1}$}

Jane Krishnadas

j.h.krishnadas@keele.ac.uk

1 Keele Law School, North Staffordshire, UK

\footnotetext{
99 Ibid.

100 Jane Krishnadas, 'CLOCK time for Justice', Legal Voice (17th February 2015).
} 